\title{
EFFECT OF FOLIAR FERTILIZATION FOR OLIVE TREES ON THE BIOACTIVE COMPOUNDS, PURITY AND ORGANOLEPTIC ATTRIBUTES OF OLIVE OILS
}

\author{
NAHED M. M. ATTA and ENAAM SH. A. MOHAMED \\ Fats and Oils Res. Dep., Food Tech. Research Institute, ARC, Giza, Egypt. \\ (Manuscript received 27 February 2017 )
}

\begin{abstract}
$\mathrm{T}$ his investigation was carried out during two seasons 2014 and 2015 at farm located EL -Nobarya, EL-Behera governorate, Egypt, to study the influence of foliar fertilization with soluation of potassium and magnesium sulphate at ratios of 3 and $5 \%$ and 0.5 and $1.5 \%$, respectively, on the organolyptic attributes, purity, overall quality index, stability, bioactive compounds (tocopherols, pigments, polyphenols and diortho phenols) and phenolic compounds of Koronaki olive oil under the environmental condition. The results were as follows : the spraying with potassium and magnesium sulphate at ratios of $5 \%$ and $1.5 \%$ foliar fertilization, respectively, gave the highest positive attribute (fruity) of olive oil, follwed by 3 and $0.5 \%$, respectively compared with the control samples in seasons 2014 and 2015, while the defect properties of olive oil were equal to zero in both treated (foliar fertilized) and untreated (control) samples during two seasons under study. Results showed that the lowest parameters for K232 and K270 nm. of olive oil were obtained when olive trees were foliar fertilization by potassium and magnesium sulphate at different concentrations in two seasons compared with control samples, while $\Delta \mathrm{k}$ recorded slight increase as a result of all previous treatments. Oleuropein, ellagic and E-vanillic phenolic compounds recorded high content compared to other phenolic compounds in the control samples while ellagic compound decreased compared with the control samples during two seasons.. Commonly, most phenolic compounds increased as a result of all folair fertilization under study. Foliar fertilization with solution of potassium and magnesium sulphate at all concentrations caused a high increment in Epi-catechin and cinamic compounds in season 2015, whilst these compounds decreased in seasons 2014 compared to control samples. But it caused decrease in carotonoids content in two seasons and also in chlorophylls content in season 2014 only. On the other hand, it caused increase in total tocopherol in two seasons with a higher value (5\%) for foliar fertilization. Therefore, folair fertilization by potassium and magnesium sulphate at different concentrations caused increment in di-o-phenols of olive oil compared to the control samples during two seasons..
\end{abstract}

Kaywords: Olive oil, organolyptic attributes, purity, polyphenols, tocophenols, pigments, di-O-phenols, overall quality index and phenolic compounds. 


\section{INTRODUCTION}

Olive (Olea europeal ) is a widely distributed tree grown healthy in many arid zone of the world native to the Mediterranean region. Olive is an overgreen tree, which are used for oil extraction and pickling. Olive fruits are considered as a rich source of phenolic compounds with a wide array of biological activities, the phenolic compounds in olives are recognized as potentially bioactive products and may have antioxidant and therapeutic properties that produce anti-cancer, anti-viral, anti-inflammatory, hypolipidaemic and hypoglycaemic effects (Obied et al., 2005). The main phenolic compounds in olive fruit are oleuropein, ligstroside, hydroxytyrosol and tyrosol (Ryan et al.,1999). Luteolin glucoside and rutin were detected only in olive peel. Similarly, Rovellini et al., (1997), analysed the flavonoid composition of fruit, husks, and leaves plus olive oil.

The pool of minor compounds may be shifted towards the accumulation of antioxidants based on the availability of precursors, enzymes activators (or co-factors ) and or other effectors, such as nutrients availability during the vegetative growth of the plant. Oil quality could be influenced by the levels of available nutrients in foliar fertilizer that is possible to optimize oil composition and to obtain the oils enriched with beneficial phytochemicals, especially polyphenols which were significantly correlated with oxidative stability ( Meriem et al., 2013 ).

Foliar application of nutrients is in general helpful to satisfy plant requirement and has a high efficiency. Potassium application to trees is an attractive method especially in arid zones where a lack of water under low rainfall conditions in summer drastically depresses absorption of soil nutrients .Potassium is known, not only to play an important role in olive yield and quality but also in water use efficiency, it is easily absorbed and distributed through leaf tissues and plays an important role in growth of olive ( Hegazi et al., 2011).

Del Rio et al., (2003) described the phenol enhancing effect of a nutrient solution. After spraying it on olive trees, several phenolic compounds ( tyrosol, catechin oleuropein) increased in leave stems roote and fruits. Besides, giving the increasing evidence of the role of nutrients and nutrient status of olive tree in the final oil quality .Potassium fertilization decreases the chlorophyll content with low value for folair treatment which could be an indication of fruit maturity, but it caused increase in polyphenols (Ben Mimoum et al., 2004).

The main objectives of this study were to study the changes in phenolic compounds, organoleptic attributes, overall quality index, purity and some bioactive compounds of olive oil as a result foliar fertilization. 


\section{MATERIALS AND METHODS}

\section{Materials:-}

1- Olive fruits: This experiment was carried out during two successive seasons (2014 \& 2015) on ten-years-old Koroneiki olive trees planted at 5 X $5 \mathrm{~m}$ and grown in sandy soil at the Experimental research station of National Research Center at El Nobarya, El Behera governorate, Egypt. The soil was characterized by: $\mathrm{pH}=8.82, \mathrm{EC}$ $=1.11 \mathrm{dS} / \mathrm{m}$, organic matter $=0.31 \%, \mathrm{CaCO} 3=12.8 \%$, Sand $=63 \%$, Silt $=13 \%$ and clay $=3 \%$. Drip irrigation system was applied using river Nile water. Trees were of normal growth, uniformed in vigour and received the same horticultural practices. The experiment followed complete randomized block design on 15 trees as 5 treatments were applied. Each tree was considered a replicate, three replicates trees per each treatment. Selected trees were sprayed with potassium sulphate $\mathrm{K}_{2} \mathrm{SO}_{4}$ ( 3 and $5 \%$ ), and magnesium sulphate $\mathrm{MgSO}_{4}$ ( 0.5 and $1.5 \%$ ) besides control (spraying with water only). The response to investigated treatments was evaluated through determining the following parameters: -

\section{Methods:-}

1. Oil extraction: $5 \mathrm{Kg}$ fruits from treated and untreated olive trees of koroneki cultivar were crushed and packed in cheese cloth then pressed using a laboratory hydraulic press. The pressure was $12.000 \mathrm{Ib} / \mathrm{in}^{2}$ for $30 \mathrm{~min} /$ one which was reached gradually. The extracted oil was dried over anhydrous sodium sulfate, through a whatman filter paper No.1 and kept in brown glass bottles at $-5^{\circ} \mathrm{C}$ till their analysis.

\section{Some chemical properties of olive oil samples:-}

- Acidity (as oleic acid \%) and peroxide values (meq $\mathrm{O}_{2} / \mathrm{kg}$ oil) were determined according to the methods of the A.O.A.C. (1995).

- Determination of fatty acid composition: The fatty acids methyl esters were prepared using trans-estrification with cold methanolic solution of potassium hydroxide. The fatty acids methyl esters were identified by GC- capillary column according to the method of IOOC (2001).

- Oxidative stability was evaluated by the Rancimat method (Mendez et al., 1997). Stability was expressed as the oxidation induction time (hours), measured with the Rancimat 679 apparatus (Metrohm Co., Switzerland), using $5 \mathrm{~g}$ oil sample and heated to $100^{\circ} \mathrm{C}$ with air flow rate of $20 \mathrm{~L} / \mathrm{h}$.

3. Organoleptic attribute: The organoleptic assessment of virgin olive oil was conducted according to the method (profile sheet) described by IOC (2007). 
4. Purity of olive oils: The purity of olive oils cab be determined from three parameters $\mathrm{K}_{232}$, $\mathrm{K}_{270} \mathrm{~nm}$ and Delta K.(Jorge and Perkin Elmer, 2008).

- Absorbancy in ultraviolet at 232, 270, 266 and $274 \mathrm{~nm}$. as deseribed by Kates (1972).

- $\Delta \mathrm{k}$ was calculated according to the method in the IOOC (2001) as the following equation:

$\Delta \mathrm{k}=\mathrm{A} 270-(\mathrm{A} 266+\mathrm{A} 274) / 2$

\section{Overall Quality Index (OQI):-}

The overall quality index (OQI) was introduced by the International Olive Oil Council (IOOC) to express virgin olive oil quality numerically (IOOC, 1990). This is a scale from 0 to 10 that considers four quality parameters: the score for sensory evaluation $(\mathrm{SE})$, free acidity (FA), $\mathrm{K}_{270}$ and peroxide value (PV) according to the following equation:

$\mathrm{OQI}=2.55+0.91 \mathrm{SE}-0.78 \mathrm{FA}-7.35 \mathrm{~K} 270-0.066 \mathrm{PV}$.

\section{Determination of some bioactive compounds in olive oil samples:-}

- Determination of total polyphenols was determined in olive oil samples according to the method of Gutfinger (1981).

- Identification of phenolic and flavonoid compounds was done by HPLC according to the methods of Goupy et al. (1999).

- Determination of total tocopherols was determined according to the method described by Wong et al.(1988).

- Determination of total pigments (chlorophyll and $\boldsymbol{\beta}$ - carotene): The chlorophylls of oil samples were determined according to the method of Mosquera et al. (1991), while the $\beta$ carotene as described by Pupin et al. (1999).

\section{RESULTS AND DISCUSSION}

\section{Chemical composition of olive oil samples:-}

As shown in Tables $(1 \& 2)$. Folair fertilization with potassium and magnesium sulphate during two seasons (2014 and 2015) caused increase for acidity in two seasons and for peroxide value in season only 2014 of olive oil compared to control sample, but it decreased in season 2015. Also, the data in the same previous tables 
showed the changes in fatty acid composition of olive oil as a result of folair fertilization for olive trees by potassium and magnesium sulphate at different percentages ( 3 and $5 \%$ ) and ( 0.5 and $1.5 \%)$, respectively, during seasons (2014 and 2015). From the results in season 2014; the saturated fatty acids found in control sample were palmitic acid (C16:0) (14.46\%) followed by stearic acid (C18:0) (2.20\%). Palmitic acid decreased in all samples, while stearic acid recorded slightly increased in all samples as a result of all folair fertilization. Oleic acid (C18:1) is the major unsaturated fatty acid in olive oil, it was $69.70 \%$ in control sample, this value increased to 72.55 and $70.94 \%$ at ratios of potassium sulphate ( 3 and $5 \%$, respectively), but decreased to 69.44 and $68.29 \%$ at ratios of magnesium sulphate ( 0.5 and $1.5 \%$, respectively). While lenolenic acid (C18:3) recorded a slightly decreased at different ratios of potassium and magnesium sulphate. On the contrary, in season 2015 folair fertilization by potassium and magnesium sulphate at different ratios caused increase in palmitic and linoleic acids (C18:2), but it caused decrease in oleic acid compared with the control samples. While linolenic acid decreased by only folair fertilization with potassium sulphate at different ratios. Generally, no clear effect of all folair fertilization was detected on total saturated fatty acids (TSFA) and total unsaturated fatty acids (TUSFA) in season 2014, but TSFA recorded slightly increase as a result of all folair fertilization contrary with TUSFA during season 2015. This difference in some chemical and fatty acid composition of olive oils as a result of folair fertilization during two season may be due to environmental conditions during the vegetable growth of the olive trees.

Table 1. Some chemical characteristices of foliar fertilized and control samples of olive oils in season 2014.

\begin{tabular}{|c|c|c|c|c|c|}
\hline \multirow{3}{*}{ Item Samples } & \multirow{3}{*}{ Control } & \multicolumn{4}{|c|}{ Foliar fertilization with } \\
\hline & & \multicolumn{2}{|c|}{$\mathrm{K}_{2} \mathrm{SO}_{4}$ at ratios of } & \multicolumn{2}{|c|}{$\mathrm{MgSO}_{4}$ at ratios of } \\
\hline & & $3 \%$ & $5 \%$ & $0.5 \%$ & $1.5 \%$ \\
\hline Acidity $\%$ & 0.13 & 0.23 & 0.51 & 0.58 & 0.71 \\
\hline $\mathrm{PV}\left(\mathrm{meq} \mathrm{O}_{2} / \mathrm{kg}\right.$ oil) & 6.58 & 7.79 & 6.47 & 8.03 & 6.10 \\
\hline $\begin{array}{l}\text { F.A. composition\%: } \\
\text { C16:0 } \\
\end{array}$ & 14.46 & 13.24 & 14.35 & 12.59 & 14.33 \\
\hline $\mathrm{C} 16: 1$ & 2.12 & 2.04 & 2.35 & 2.11 & 2.26 \\
\hline C18:0 & 2.20 & 2.36 & 2.33 & 2.5 & 2.54 \\
\hline C18:1 & 69.70 & 72.55 & 70.94 & 69.44 & 68.29 \\
\hline C18:2 & 10.76 & 8.98 & 9.33 & 12.61 & 11.85 \\
\hline $\mathrm{C} 18: 3$ & 0.76 & 0.7 & 0.70 & 0.75 & 0.73 \\
\hline TSFA & 16.66 & 15.60 & 16.68 & 15.09 & 16.87 \\
\hline TUSFA & 83.34 & 84.4 & 83.32 & 84.91 & 83.13 \\
\hline
\end{tabular}


Table 2. Some chemical characteristices of foliar fertilized and control samples of olive oils in season 2015:

\begin{tabular}{|c|c|c|c|c|c|}
\hline \multirow{3}{*}{ Item } & \multirow[t]{3}{*}{ Control } & \multicolumn{4}{|c|}{ Foliar fertilization with } \\
\hline & & \multicolumn{2}{|c|}{$\mathrm{K}_{2} \mathrm{SO}_{4}$ at ratios of } & \multicolumn{2}{|c|}{$\mathrm{MgSO}_{4}$ at ratios of } \\
\hline & & $3 \%$ & $5 \%$ & $0.5 \%$ & $1.5 \%$ \\
\hline Acidity $\%$ & 0.08 & 0.17 & 0.15 & 0.12 & 0.15 \\
\hline $\mathrm{PV}$ (meq $\mathrm{O}_{2} / \mathrm{kg}$ oil) & 1.16 & 1.00 & 0.84 & 0.77 & 0.76 \\
\hline F.A. composition\%: & & & & & \\
\hline $\mathrm{C} 16: 0$ & 14.76 & 16.09 & 15.5 & 15.60 & 15.08 \\
\hline $\mathrm{C} 16: 1$ & 2.24 & 2.48 & 1.91 & 2.18 & 2.23 \\
\hline $\mathrm{C} 18: 0$ & 2.28 & 2.04 & 1.95 & 2.28 & 2.15 \\
\hline C18:1 & 72.38 & 69.66 & 70.55 & 70.76 & 71.2 \\
\hline $\mathrm{C} 18: 2$ & 7.45 & 9.15 & 9.26 & 8.21 & 8.44 \\
\hline $\mathrm{C} 18: 3$ & 0.89 & 0.85 & 0.83 & 0.97 & 0.9 \\
\hline TSFA & 17.04 & 18.13 & 17.45 & 17.88 & 17.23 \\
\hline TUSFA & 82.96 & 81.87 & 82.55 & 82.12 & 82.77 \\
\hline
\end{tabular}

\section{Effect of foliar fertilization on the organoleptic attributes of olive oil samples:}

Data in Tables (3 and 4) indicate the influence of folair fertilization with potassium and magnesium sulphate at ( 3 and $5 \%)$ and ( 0.5 and $1.5 \%)$ respectively, on the organolyptic attributes of olive oils in both two seasons 2014 and 2015 . Potassium sulphate at $5 \%$ and magnesium sulphate at $1.5 \%$ gave the highest fruity attribute (3.5 and 3.75) of olive oil respectively, followed by potassium and magnesium sulphate at 3 and $0.5 \%$, respectively, while control treatment gave the lowest fruity (2.00) in the season 2014 . Also, in season 2015 , folair fertilization with potassium and magnesium sulphate at different percentages gave the highest positive properties ( fruity attribute ), in contrast the control treatment gave the lowest fruity attribute (2.5). Concerning the defect properties of olive oils, they were equal zero in both treated (folair fertilized) and untreated (control) samples in two seasons. Generally, all positive properties of olive oils recorded higher increment as resulting of folair fertilization compared with control sample. This result may be attributed to the highest content of total polyphenol, especially oleuropein, ( which responsible for the bitternes attribute) in olive oil under study (as will shown in Table 11). 
Table 3. Effect of foliar fertilization on the organoleptic attributes of olive oil samples in season 2014.

\begin{tabular}{|c|c|c|c|c|c|}
\hline \multirow{3}{*}{$\begin{array}{c}\text { Organoleptic } \\
\text { attributes }\end{array}$} & \multirow{3}{*}{ Control } & \multicolumn{4}{|c|}{ Foliar fertilization with } \\
\hline & & \multicolumn{2}{|c|}{$\mathrm{K}_{2} \mathrm{SO}_{4}$ at ratios of } & \multicolumn{2}{|c|}{$\mathrm{MgSO}_{4}$ at ratios of } \\
\hline & & $3 \%$ & $5 \%$ & $0.5 \%$ & $1.5 \%$ \\
\hline \multicolumn{6}{|l|}{ Positive attributes : } \\
\hline fruity & 2.00 & 3.00 & 3.50 . & 3.00 & 3.75 \\
\hline bitternes & 0.50 & 1.25 & 1.00 & 1.50 & 1.00 \\
\hline punget & 0.75 & 0.75 & 0.75 & 1.00 & 1.00 \\
\hline Defect properties & 0.00 & 0.00 & 0.00 & 0.00 & 0.00 \\
\hline
\end{tabular}

Table 4. Effect of foliar fertilization on the organoleptic attributes of olive oil samples in season 2015.

\begin{tabular}{|c|c|c|c|c|c|}
\hline \multirow{3}{*}{$\begin{array}{c}\text { Organoleptic } \\
\text { attributes }\end{array}$} & \multirow{3}{*}{ Control } & \multicolumn{4}{|c|}{ Foliar fertilization with } \\
\hline & & \multicolumn{2}{|c|}{$\mathrm{K}_{2} \mathrm{SO}_{4}$ at ratios of } & \multicolumn{2}{|c|}{$\mathrm{MgSO}_{4}$ at ratios of } \\
\hline & & $3 \%$ & $5 \%$ & $0.5 \%$ & $1.5 \%$ \\
\hline \multicolumn{6}{|l|}{ Positive attributes : } \\
\hline fruity & 2.50 & 3.00 & 3.20 & 2.75 & 3.60 \\
\hline bitternes & 1.00 & 2.75 & 1.25 & 2.25 & 1.50 \\
\hline punget & 1.50 & 2.50 & 2.00 & 3.00 & 3.00 \\
\hline Defect properties & 0.00 & 0.00 & 0.00 & 0.00 & 0.00 \\
\hline
\end{tabular}

\section{Effect of foliar fertilization on the purity of olive oil samples:}

The purity of the olive oil was studied by measuring the characteristic of absorption bands between 200 and $300 \mathrm{~nm}$. These are frequencies related to conjugated diene and triene systems. A low absorption in this region is indicative of a high quality extra virgin olive oil . The purity of olive oil can be determined from three parameters; $\mathrm{K}_{232} \mathrm{~K}_{270}$ (absorpance at 232 and $270 \mathrm{~nm}$.) and Delta k (Jorge and Perkin Elmer, 2008). Data presented in Tables (5 and 6) recorded that the lowest parameters ( $K_{232}$ and $K_{270}$ ) of olive oils were observed in the two seasons (2014 \& 2015) when olive trees were foliar fertilization by potassium and magnesium sulphate foliar fertilization at different concentrations, while control treatment gave the highest $\mathrm{K}_{232}$ and $K_{270}$ of oils in both seasons. On the contrary, Delta $K(\Delta \mathrm{k})$ of oil recorded a slight increment as a result of previous treatments compared to control samples in two seasons. The lowest $K_{232}$ and $K_{270} \mathrm{~nm}$. may be influenced by the levels of available nutrients in folair fertilizer which is possible to obtain oils enriched with beneficial 
phytochemicals especially polyphenols which preserved the oil from deterioration and oxidation. This is related to decrease in the $\mathrm{K}_{232}$ and $\mathrm{K}_{270} \mathrm{~nm}$. of oil .

Table 5. Effect of foliar fertilization on the purity of olive oil samples in season 2014.

\begin{tabular}{|c|c|c|c|c|c|}
\hline \multirow{2}{*}{ Surity } & \multirow{2}{*}{ Control } & \multicolumn{4}{|c|}{ Foliar fertilization with } \\
\cline { 3 - 6 } & & \multicolumn{2}{|c|}{ K2SO4 at ratios of } & \multicolumn{2}{c|}{ MgSo4 at ratios of } \\
\cline { 3 - 6 } & & $\mathbf{3 \%}$ & $\mathbf{5 \%}$ & $\mathbf{0 . 5 \%}$ & $\mathbf{1 . 5 \%}$ \\
\hline $\mathrm{K}_{232} \mathrm{~nm}$. & 1.867 & 1.795 & 1.660 & 1.660 & 1.76 \\
\hline $\mathrm{K}_{270} \mathrm{~nm}$. & 0.140 & 0.110 & 0.107 & 0.111 & 0.134 \\
\hline$\Delta \mathrm{k}$ & 0.0005 & 0.005 & 0.002 & 0.001 & 0.001 \\
\hline
\end{tabular}

Table 6. Effect of foliar fertilization on the purity of olive oil samples in season 2015.

\begin{tabular}{|c|c|c|c|c|c|}
\hline \multirow{3}{*}{ Purity } & \multirow{3}{*}{ Control } & \multicolumn{4}{|c|}{ Foliar fertilization with } \\
\hline & & \multicolumn{2}{|c|}{$\mathrm{K}_{2} \mathrm{So}_{4}$ at ratios of } & \multicolumn{2}{|c|}{$\mathrm{MgSO}_{4}$ at ratios of } \\
\hline & & $3 \%$ & $5 \%$ & $0.5 \%$ & $1.5 \%$ \\
\hline $\mathrm{K}_{232} \mathrm{~nm}$. & 1.939 & 1.783 & 1.640 & 1.803 & 1.872 \\
\hline $\mathrm{K}_{270} \mathrm{~nm}$ & 0.171 & 0.098 & 0.115 & 0.132 & 0.136 \\
\hline$\Delta \mathrm{k}$ & -0.003 & -0.002 & -0.001 & -0.002 & -0.001 \\
\hline
\end{tabular}

Effect of foliar fertilization on some bioactive compounds of olive oil samples:

Data in Tables (7 and 8) show that effect of the foliar fertilization with potassium and magnesium sulphate ( 3 and $5 \%$ ) and ( 0.5 and $1.5 \%$, respectively on some bioactive compounds of olive oils during seasons (2014 and 2015). From these results, it could be observed that foliar fertilization with potassium sulphate at ratios of 3 and 5\% in seasons 2014 and 2015 caused increase in total polyphenols of olive oils. On the other hand, foliar fertilization with magnesium sulphate at ratio of 0.5 and $1.5 \%$ occurred decrements in two seasons compared with the control samples. While di-ortho-phenols recorded a higher increase as a results of folair fertilization by potassium and magnesium sulphate at different treatments in two seasons compared with control samples. Potassium sulphate at (5\%) foliar fertilization caused increase in the total tocopherols at ratios of 69.18 and $24.6 \%$, respectively, in both seasons compared to the control sample, but magnesium sulphate $(1.5 \%)$ foliar fertilization increase the total tocopherols at ratio of $55.14 \%$ in only season 2014 . On the other hand, potassium and magnesium sulphate foliar fertilization at different ratios decrease 
in the carotonoids and chlorophylls contents of olive oils in season 2014, while chlorophyll contents recorded increments in season 2015. Also magnesium sulphate foliar fertilization at different treatments increased the carotenoids at ratios of 28.45 and $12.2 \%$, respectively while potassium sulphate foliar fertilization at 3 and $5 \%$ decreased it at ratios of -21.10 and $-13.8 \%$, respectively in the same season (2015) . This may be due to change in enviromental conditions.

Table 7. Effect of foliar fertilization on some bioactive compounds of olive oil samples in season 2014.

\begin{tabular}{|c|c|c|c|c|c|}
\hline \multirow{3}{*}{ Item } & \multirow{3}{*}{ Control } & \multicolumn{4}{|c|}{ Foliar fertilization with } \\
\hline & & \multicolumn{2}{|c|}{$\mathrm{K}_{2} \mathrm{SO}_{4}$ at ratios of } & \multicolumn{2}{|c|}{$\mathrm{MgSO}_{4}$ at ratios of } \\
\hline & & $3 \%$ & $5 \%$ & $0.5 \%$ & $1.5 \%$ \\
\hline T.Polyphenol (ppm) & 201.20 & 225.62 & 242.80 & 182.30 & 193.37 \\
\hline Di-o-phenols (ppm) & 27.65 & 35.99 & 29.15 & 28.00 & 30.12 \\
\hline T.tocophenol (ppm) & 35.18 & 22.05 & 59.52 & 16.02 & 54.58 \\
\hline \multicolumn{6}{|l|}{ Pigments (mg/kg):- } \\
\hline Carotonoids & 0.88 & 0.79 & 0.76 & 0.76 & 0.73 \\
\hline Chlorophylls & 1.63 & 1.50 & 1.39 & 1.38 & 1.34 \\
\hline
\end{tabular}

Table 8. Effect of foliar fertilization on some bioactive compounds of olive oil samples in season 2015.

\begin{tabular}{|c|c|c|c|c|c|}
\hline \multirow{3}{*}{ Item } & \multirow{3}{*}{ Control } & \multicolumn{4}{|c|}{ Foliar fertilization with } \\
\hline & & \multicolumn{2}{|c|}{$\mathrm{K}_{2} \mathrm{SO}_{4}$ at ratios of } & \multicolumn{2}{|c|}{$\mathrm{MgSo}_{4}$ at ratios of } \\
\hline & & $3 \%$ & $5 \%$ & $0.5 \%$ & $1.5 \%$ \\
\hline T.Polyphenol (ppm) & 312.28 & 357.40 & 402.17 & 287.10 & 297.91 \\
\hline Di-o-phenols (ppm) & 42.9 & 57.01 & 44.97 & 44.09 & 46.44 \\
\hline T.tocophenol (ppm) & 85.06 & 68.67 & 106.02 & 77.83 & 61.20 \\
\hline \multicolumn{6}{|l|}{ Pigments (mg/kg):- } \\
\hline Carotonoids & 1.23 & 0.97 & 1.06 & 1.58 & 1.38 \\
\hline Chlorophylls & 1.63 & 1.70 & 1.75 & 2.64 & 2.76 \\
\hline
\end{tabular}

Effect of foliar fertilization on the overall quality index (OQI), some ratios of

\section{fatty acids and oxidative stability of olive oil samples:}

There are three most important parameters related to fatty acid composition of any oil, The first is the ratio of total saturated fatty acids / total unsaturated fatty acids (T.SFA/T.USFA) which related to the oxidation stability of oil, while the second is oleic acid/ lenoleic acid (C18:1/C18:2) ratio which has a positive effect on the taste of the 
oil ( Ranal et al., 2001 ). The third is lenoleic acid/palmitic acid ratio (C18:2/C16:0) which indicate the degree of oxidative deterioration of oils, espicailly frying oil ( CheMan and Tan 1999). Generally, results in Tables (9 and 10) indicated that the ratio of C18:1/C18:2, C18:2/C16:0, T.SFA/T.USFA, oxidative stability and OQI of olive oil were affected by different folair fertilization with potassium and magnesium sulphate in both seasons 2014 and 2015.

From the results season ( 2014), It is clear that, foliar application of potassium sulphate at 3 and $5 \%$ occurred increase in C18:1/C18:2 ratio, but it caused decrease in C18:2/C16:0 ratio compared with the control samples, contrary with foliar application with magnesium sulphate at 0.5 and $1.5 \%$. On the other hand, potassium and magnesium sulphate folair fertilization caused slight increase in the TSFA/TUSFA ratio with high values for folair treatments at 5 and $1.5 \%$ respectively, but its caused slight decrease it with low values ( at $3 \%$ and $0.5 \%$ ). While the OQI of all olive oils increased as a results all folair fertilization under investigation. With concerning the previous parameters of olive oils obtained from season 2015, it is obvious from Table (10) that, potassium and magnesium sulphate foliar fertilization occurred decrease in the $\mathrm{C} 18: 1 / \mathrm{C} 18: 2$ ratios for all samples compared to control samples, but these caused increase in OQI for all samples, while C18:2/C16:0 and TSFA/TUSFA ratios, its nearly the same as a result of folair fertilization. Also, the oxidative stability of olive oil affected by different folair fertilization in the first and second seasons (2014 and 2015). Potassium sulphate at 3 and 5\% gave the highest oxidative stability, while magnesium sulphate gave the lowest oxidative stability at 0.5 and $1.5 \%$ compared to the control samples during two seasons. The increase in the stability of olive oil as a result of folair fertilization with potassium sulphate at ( 3 and $5 \%$ ) may be influenced by the levels of available nutrients in folair fertilizer is which possible to obtain oils enriched with beneficial phytochemicals especially polyphenols which were significantly correlated with oxidative stability ( Meriem et al., 2013 ).

Table 9. Effect of foliar fertilization on the overall quality index (OQI), some ratios of fatty acids and oxidative stability of olive oil samples in season 2014.

\begin{tabular}{|c|c|c|c|c|c|}
\hline \multirow[b]{3}{*}{ Item } & \multirow{3}{*}{ Control } & \multicolumn{4}{|c|}{ Foliar fertilization with } \\
\hline & & \multicolumn{2}{|c|}{$\mathrm{K}_{2} \mathrm{SO}_{4}$ at ratios of } & \multicolumn{2}{|c|}{$\mathrm{MgSO}_{4}$ at ratios of } \\
\hline & & $3 \%$ & $5 \%$ & $0.5 \%$ & $1.5 \%$ \\
\hline $\mathrm{C} 18: 1 / \mathrm{C} 18: 2$ & 6.48 & 8.08 & 7.6 & 5.51 & 5.76 \\
\hline $\mathrm{C} 18: 2 / \mathrm{C} 16: 0$ & 0.74 & 0.68 & 0.65 & 1.00 & 0.83 \\
\hline TSFA/TUSFA & 0.199 & 0.178 & 0.203 & 0.185 & 0.200 \\
\hline Oxidative stability (hr.) at $100{ }^{\circ} \mathrm{C}$ & 34.90 & 43.10 & 44.73 & 32.31 & 32.73 \\
\hline OQI & 2.83 & 3.17 & 3.76 & 3.10 & 4.32 \\
\hline
\end{tabular}


Table 10. Effect of foliar fertilization on the overall quality index (OQI), some ratios of fatty acids and oxidative stability of olive oil samples in season 2015.

\begin{tabular}{|l|c|c|c|c|c|}
\hline \multirow{2}{*}{ Samples } & \multirow{2}{*}{ Control } & \multicolumn{4}{c|}{ Foliar fertilization with } \\
\cline { 4 - 6 } & & \multirow{2}{*}{ K2SO4 at ratios of } & \multicolumn{2}{c|}{ MgSo4 at ratios of } \\
\cline { 4 - 6 } Item & & $\mathbf{3 \%}$ & $\mathbf{5 \%}$ & $\mathbf{0 . 5 \%}$ & $\mathbf{1 . 5 \%}$ \\
\hline C18:1/C18:2 & & & & & \\
\hline C18:2/C16:0 & 9.66 & 7.61 & 7.62 & 8.62 & 8.44 \\
\hline TSFA/TUSFA & 0.51 & 0.57 & 0.62 & 0.53 & 0.56 \\
\hline Oxidative Stability (hr.) at $100{ }^{\circ} \mathrm{C}$ & 0.205 & 0.22 & 0.21 & 0.22 & 0.21 \\
\hline OQI & 39.5 & 43.89 & 45.14 & 33.85 & 33.48 \\
\hline
\end{tabular}

\section{Effect of foliar fertilization on the phenolic compounds of olive oil samples:-}

Phenolic compounds of olive oil have been of major interest to researchers due to their positive effects on both human health and preservation of olive oil . Results in Tables (11 and 12) show the influence of folair fertilization by potassium and magnesium sulphate at different concentrations

( 3 and 5\%) and ( 0.5 and 1.5\% ) respectively during two seasons (2014 and 2015) on the phenolic compounds of olive oils. From these results, it could be noticed that, twinty five phenolic compounds were detected in all olive oil samples, whereas Evanillic, oleuropein and ellagic compounds recorded a high levels, followed by benzoic, Epi-catechin, pyrogallol, salicylic and alph-coumaric compounds comparing with other phenolic compounds in control and treated samples during two seasons. From the results, it could be observed that, the concentration of all phenolic compounds were increased especially, E-vanillic, oleuropein and salicylic compounds at different treatments. While ellagic, Epi-catechin and cinamic compounds decreased as a results of folair fertilization, in season 2014, but Epi-catechin and cinamic compounds increased in season 2015 by potassium and magnesium sulphate at different treatments. As shown previously, the rate of increase for catechin , catechol, coumarin and protocatchouic phenolic compounds as a result of the folair fertilization by potassium sulphate was more pronounced than those obtained by the folair fertilization with magnesium sulphate in two seasons. This increase in phenolic compounds of olive oils as a result of folair fertilization under study may be due to the role of neuitrants in folair fertelizer I in ameliorating the biosynthesic of phenolic oil in plants. 
Table 11. Effect of foliar fertilization on the phenolic compounds (ppm) of olive oil samples in season 2014.

\begin{tabular}{|l|c|c|c|c|c|}
\multirow{2}{*}{ Samples } & \multirow{2}{*}{ Control } & \multicolumn{4}{|c|}{ Foliar fertilization with } \\
\cline { 3 - 6 } & & \multicolumn{3}{|c}{ K2S04 at ratios of } & \multicolumn{2}{c|}{ MgSo4 at ratios of } \\
\cline { 3 - 6 } & & $\mathbf{3 \%}$ & $\mathbf{5 \%}$ & $\mathbf{0 . 5 \%}$ & $\mathbf{1 . 5 \%}$ \\
\hline pyrogallol & 12.39 & 14.80 & 16.30 & 25.30 & 13.93 \\
\hline Gallic & 0.54 & 0.74 & 0.94 & 0.64 & 0.84 \\
\hline 4-amino benzoic acid & 0.25 & 0.99 & 0.88 & 0.47 & 0.39 \\
\hline Catechin & 3.08 & 14.62 & 22.49 & 3.65 & 4.17 \\
\hline Chlorogenic & 1.26 & 2.36 & 3.30 & 7.97 & 2.35 \\
\hline Catechol & 2.35 & 4.50 & 6.77 & 1.7 & 1.36 \\
\hline Oleuropein & 183.32 & 365.14 & 309.03 & 451.74 & 331.98 \\
\hline Epi-catechin & 15.01 & 7.68 & 6.40 & 12.01 & 8.59 \\
\hline Caffeine & 0.42 & 1.25 & 0.94 & 1.82 & 0.95 \\
\hline p-OH-benzoic & 0.58 & 2.72 & 3.72 & 3.65 & 4.90 \\
\hline Caffeic & 0.80 & 0.61 & 1.24 & 0.66 & 0.81 \\
\hline Vanillic & 1.28 & 2.66 & 3.53 & 2.28 & 3.11 \\
\hline p-coumaric & 1.87 & 1.99 & 2.96 & 2.42 & 3.65 \\
\hline Ferulic & 1.46 & 4.97 & 6.89 & 1.52 & 1.70 \\
\hline Iso-ferulic & 1.44 & 1.46 & 4.52 & 2.71 & 1.98 \\
\hline Resveratol & 0.46 & 1.38 & 3.16 & 1.96 & 1.05 \\
\hline Ellagic & 96.36 & 73.79 & 63.75 & 93.09 & 58.59 \\
\hline E-vanillic & 247.49 & 497.49 & 402.21 & 595.88 & 365.20 \\
\hline Alpha-coumaric & 9.43 & 11.78 & 12.87 & 15.21 & 19.12 \\
\hline Benzoic & 18.93 & 20.44 & 22.10 & 36.53 & 19.47 \\
\hline $3,4,5$ methoxy cinamic & 3.89 & 4.40 & 7.07 & 4.9 & 4.79 \\
\hline Coumarin & 2.89 & 6.86 & 7.89 & 3.99 & 3.55 \\
\hline Salicylic & 14.83 & 24.46 & 28.19 & 33.5 & 30.37 \\
\hline Cinamic & 2.67 & 1.57 & 0.96 & 1.38 & 1.74 \\
\hline Protocatchouic & 3.11 & 10.67 & 6.67 & 2.56 & 1.13 \\
\hline & & & & & \\
\hline
\end{tabular}

Table 12. Effect of foliar fertilization on the phenolic compounds (ppm) of olive oil samples in season 2015.

\begin{tabular}{|c|c|c|c|c|c|}
\hline \multirow[t]{3}{*}{ Samples } & \multirow{3}{*}{ Control } & \multicolumn{4}{|c|}{ Foliar fertilization with } \\
\hline & & \multicolumn{2}{|c|}{$\mathrm{K}_{2} \mathrm{SO}_{4}$ at ratios of } & \multicolumn{2}{|c|}{$\mathrm{MgSO}_{4}$ at ratios of } \\
\hline & & $3 \%$ & $5 \%$ & $0.5 \%$ & $1.5 \%$ \\
\hline pyrogallol & 19.65 & 84.32 & 114.05 & 40.70 & 25.56 \\
\hline Gallic & 0.22 & 0.72 & 0.87 & 0.25 & 0.38 \\
\hline 4-amino benzoic acid & 0.51 & 1.28 & 1.07 & 0.73 & 0.66 \\
\hline Catechin & 1.41 & 23.37 & 26.47 & 2.66 & 6.64 \\
\hline Chlorogenic & 1.30 & 9.44 & 12.08 & 17.71 & 5.94 \\
\hline Catechol & 4.75 & 6.34 & 8.56 & 2.9 & 3.18 \\
\hline Oleuropein & 242.77 & 508.34 & 407.00 & 497.67 & 443.66 \\
\hline Epi-catechin & 20.57 & 62.02 & 64.27 & 52.12 & 56.33 \\
\hline Caffeine & 1.40 & 4.70 & 4.37 & 5.12 & 1.70 \\
\hline p-OH-benzoic & 1.76 & 4.78 & 4.42 & 5.54 & 6.92 \\
\hline Caffeic & 0.98 & 1.39 & 1.95 & 1.71 & 1.07 \\
\hline Vanillic & 3.83 & 5.85 & 6.45 & 4.19 & 4.66 \\
\hline p-coumaric & 1.71 & 2.84 & 14.95 & 3.54 & 5.88 \\
\hline Ferulic & 1.10 & 2.02 & 2.75 & 1.20 & 1.42 \\
\hline Iso-ferulic & 1.96 & 2.40 & 15.25 & 3.65 & 2.34 \\
\hline Resveratol & 1.29 & 2.29 & 3.57 & 2.45 & 1.61 \\
\hline Ellagic & 111.20 & 75.20 & 63.80 & 99.95 & 60.25 \\
\hline E-vanillic & 358.10 & 510.44 & 511.29 & 503.63 & 520.69 \\
\hline Alpha-coumaric & 16.07 & 18.32 & 21.10 & 17.94 & 17.82 \\
\hline Benzoic & 24.61 & 25.98 & 31.21 & 48.11 & 26.66 \\
\hline $3,4,5$ methoxy cinamic & 4.13 & 4.57 & 7.71 & 7.31 & 6.27 \\
\hline Coumarin & 2.05 & 6.73 & 7.08 & 5.93 & 5.12 \\
\hline Salicylic & 9.64 & 23.35 & 42.24 & 21.06 & 36.40 \\
\hline Cinamic & 1.07 & 5.71 & 5.95 & 6.28 & 11.49 \\
\hline Protocatchouic & 4.16 & 13.05 & 11.44 & 5.96 & 4.21 \\
\hline
\end{tabular}




\section{Effect of foliar fertilization on the flavonoid compounds of olive oil samples}

Flavonoids play an important role in the quality of virgin olive oil because of their antioxidant activity. As shown in Tables (13 and 14 ), naringenin compound recorded a high level in season 2014 followed by rutin hispirdin and luteolin compounds, while luteolin compound recorded the highest content in season 2015 followed by naringenin and hispirdin compared with those in control sample. Also, the data show that, luteolin, apigenin, rosmarinic, naringenin, quecetrin, hispirdin, rutin compounds recorded increments in two (seasons 2014 and 2015), while the values of kaempferol, quercietin and narigin compounds decreased by folair fertilization compared with the control sample in season 2014. On the other hand, apigenin, kaempferol, hespirtin, naringenin, quercitin and hispirdin compounds recorded increase, but lutin, rosmarinic, quecetrin, rutin and naringin compounds decreased as a result folair fertilization in season 2015. Commonly, most flavonoid compounds in season 2014 recorded increase with folair fertilization by potassium and magnesium sulphate at different treatments.

Table 13. Effect of foliar fertilization on the flavonoid compounds (ppm) of olive oil samples in season 2014.

\begin{tabular}{|c|c|c|c|c|c|}
\hline \multirow{3}{*}{ Item } & \multirow{3}{*}{ Control } & \multicolumn{4}{|c|}{ Foliar fertilization with } \\
\hline & & \multicolumn{2}{|c|}{$\mathrm{K}_{2} \mathrm{SO}_{4}$ at ratios of } & \multicolumn{2}{|c|}{$\mathrm{MgSO}_{4}$ at ratios of } \\
\hline & & $3 \%$ & $5 \%$ & $0.5 \%$ & $1.5 \%$ \\
\hline Luteolin & 0.001 & 0.00718 & 0.00606 & 0.00562 & 0.0052 \\
\hline Apigenin & 0.00030 & 0.00035 & 0.00040 & 0.00030 & 0.00050 \\
\hline Rosmarinic & 0.00002 & 0.00006 & 0.00016 & 0.00009 & 0.00005 \\
\hline Kaempferol & 0.00055 & 0.00049 & 0.00023 & 0.00034 & 0.00026 \\
\hline Hespirtin & 0.00053 & 0.00048 & 0.00219 & 0.00011 & 0.00072 \\
\hline Naringenin & 0.00053 & 0.00062 & 0.00073 & 0.0006 & 0.00083 \\
\hline Quercitin & 0.00030 & 0.00025 & 0.00022 & 0.00028 & 0.00015 \\
\hline Quecetrin & 0.00014 & 0.00015 & 0.00016 & 0.00016 & 0.00018 \\
\hline Hispirdin & 0.00129 & 0.00143 & 0.00208 & 0.0014 & 0.00209 \\
\hline Rutin & 0.00051 & 0.00166 & 0.00056 & 0.00143 & 0.00142 \\
\hline Naringin & 0.05624 & 0.00167 & 0.00150 & 0.00061 & 0.00055 \\
\hline
\end{tabular}


Table 14. Effect of foliar fertilization on the flavonoid compounds (ppm) of olive oil samples in season 2015.

\begin{tabular}{|c|c|c|c|c|c|}
\hline \multirow{3}{*}{ Item } & \multirow{3}{*}{ Control } & \multicolumn{4}{|c|}{ Foliar fertilization with } \\
\hline & & \multicolumn{2}{|c|}{$\mathrm{K}_{2} \mathrm{SO}_{4}$ at ratios of } & \multicolumn{2}{|c|}{$\mathrm{MgSO}_{4}$ at ratios of } \\
\hline & & $3 \%$ & $5 \%$ & $0.5 \%$ & $1.5 \%$ \\
\hline Luteolin & 0.00773 & 0.00047 & 0.00222 & 0.00164 & 0.00504 \\
\hline Apigenin & 0.00025 & 0.00031 & 0.00033 & 0.00075 & 0.00064 \\
\hline Rosmarinic & 0.00028 & 0.00019 & 0.00027 & 0.00017 & 0.00016 \\
\hline Kaempferol & 0.00029 & 0.00040 & 0.00052 & 0.00030 & 0.00070 \\
\hline Hespirtin & 0.00030 & 0.00066 & 0.00477 & 0.00066 & 0.00104 \\
\hline Naringenin & 0.00050 & 0.00078 & 0.00123 & 0.00056 & 0.00134 \\
\hline Quercitin & 0.00011 & 0.00017 & 0.00078 & 0.00047 & 0.00029 \\
\hline Quecetrin & 0.00043 & 0.00038 & 0.00039 & 0.00022 & 0.00030 \\
\hline Hispirdin & 0.00183 & 0.00264 & 0.00549 & 0.00333 & 0.00256 \\
\hline Rutin & 0.00252 & 0.00059 & 0.000203 & 0.00117 & 0.00249 \\
\hline Naringin & 0.00208 & 0.00079 & 0.00151 & 0.00168 & 0.00201 \\
\hline
\end{tabular}

\section{CONCLUSION}

From all the above results, it can be concluded that, olive oils obtained from olive fruits trees treated with folair fertilization with solution of potassium and magnesium sulphate at all concentrations were the best in organolyptic attributes, purity, the total polyphenol, di-o- phenols, overall quality index, total tocopherols and the major phenolic compounds compared to those obtained from the control samples.

Folair fertilization by solution of potassium sulphate at ratios of 3 and $5 \%$ for olive trees gave the highest stability of the oils extracted from their fruits compared to the other samples in two seasons under study.

\section{REFERENCES}

1. A.O.A.C. 1995. Official methods of analysis of the association of the analytical chemists published by the A.O.A.C. international $16^{\text {th }}$ edition, Washington D.C.USA.

2. Ben mimoun, M.; O. Loumi; M. Ghrab; K. Latiri and R. Hellali. 2004. Foliar potassium application on olive tree. IPI regional workshop on potassium and 
fertigation development in west Asia and North Africa; Rabat, Morocco, 24-28 November.

3. Che-Man, Y. B. and C. P. Tan. 1999. Effect of natural and synthetic antioxidants on changes in refined, bleached and deodorized palm olein during deep-fat frying of potato chips. J.Am.Oil Chem.Soc., 76 (3): 331-339.

4. Del Rio JA; AG, Baidez; JM Botia and Aortuno. 2003. Enhancement of phenolic compounds in olive plants (Olea europeal) and their influence on resistance against phytophora sp. Food Chem., 83:75-78 .

5. Goupy, P; M. Hugues; P. Biouin and M. J. Amiot. 1999. Antioxidant composition and activity of barley ( Hordeumvulgare) and malt extracts and isolated phenolic compounds. J.Sci. Food Agric., 79: 16250-16340.

6. Gutfinger, T. 1981. Polyphenols in olive oils. J.Am.Oil Chem. Soc.,61 (9): 966-968.

7. Hegazi, E.S. ; M. M. Samira; M.R.El-Sonbaty ; S. K. M. Abd El-Naby and T. F. ELSharony. 2011. effect of potassium nitrate on vegetative growth, nutritional status, yield and fruit quality of olive cv."picual",J. Hort, SCI. and Ornamen. Plants, 3 (3), 252 - 258.

8. IOC. 2007. International Olive Council, Organoleptic assessment of virgin olive oil. 20 september French.

9. IOOC. 1990. International Olive Oil Council, Activities of cooperation technique. Olivae, 38, 12.

10. IOOC. 2001. Method of analysis of the International Olive Oil Council preparation of the fatty acid methyl esters from olive oil and olive pomace oil CO/T.20/DOC. No.24.

11. Jorge. P. and E. A. perkin Elmer. 2008. Determination of olive oil purity and degree of oxidation using the LANBDA XLS. Encuartes, 19 Tres Cantos, Madrid 28760, Spain (WWW. perkinelmer. Com).

12. Kates, N. 1972. Technique of lipidology American Elsevir Publishing Co-Inc. New york. Pyka, A. and Sliwio, K. 2001. Chromatographic separation of tocopherols. J. of Chromatography, 935: 71-76.

13. Mendez, E.;J.Sanhueza; H. Speisky and A. Valenzuela. 1997. Comparison of Rancimat evaluation methods to assess oxidative stability of fish oil. J.Am. Oil Chem. Soc., 79 (3) 331-332.

14. Meriem,T.; M. Beligh; B. Amani; A. Faouzi; Ch. Hechmi and D. Mohamed. 2013. Enhancement of antioxidants in olive oil by Foliar fertilization of olive trees.J. Am.Oil Chem. Soc., 90:1377-1386. 
15. Mosquora, M. M. L.; N. L. Rejano; R. B. Gandul; G. A. Sanchez; and F. J. Garrido. 1991. Color pigments correlation in virgin olive oil. J.Am. Oil Chem. SOC., 68,332336.

16. Obied, H, K.; M. S. Allen; D. R. Bedgood; P.D.Prenzler; K. Robards and R. Stockman (2005): Bioactivity and analysis of biophenols recovered from olive mill waste. Journal of Agricultural and Food Chemistry 53:823-837.

17. Pupin, A. M.; M. J. Dennis; and M. C. F. Tolodo. 1999. HPLC analysis of carotenoids in orange juice. Food Chem. 64, 269-275.

18. Ranal, A.; S. Contento; C. Schiavone and N. Simone. 2001. Malaxing temperature affects: Volatile and phenol composition as well as other analytical features of virgin olive oil. Eur J Lipid Sci. Tech 103:228-238.

19. Rovellini, P.; N. Cortesi and E. Fedeli. 1997. Analysis of flavonoids from Olea euroea by HPLC-UV and HPLC-electrospray-MS. Rivista Italiana Delle Sostanze Grasse 74: 273-279.

20. Ryan, D.; K. Robards and S. Lavee. 1999. Changes in phenolic content of olive during maturation. International Journal of Food Science and Technology, 34: 265-274.

21. Wong, M. L.; R.E. Timms and E.M. Cioh. 1988. Colormetric determination of total tocopherols in palm oil, olein and stearin. J.Am.Oil Chem.Soc., (2): 258-261. 


\section{تأثير الرش الورقى لاثجار الزيتون على المركبات الحيوية والنقاوة و الخواص الحسية لزيت الزيتون}

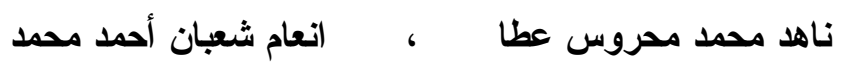

قسم بحوث الزيوت والدهون - معهد بحوث تكنولوجيا الاغذية - مركز البحوث الزراعية - الجيزة

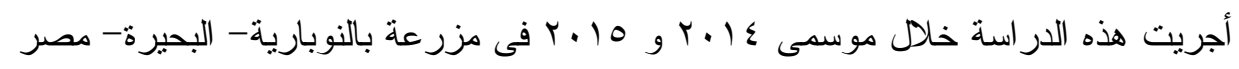

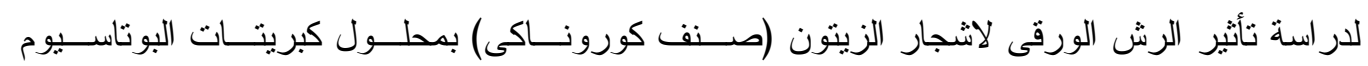

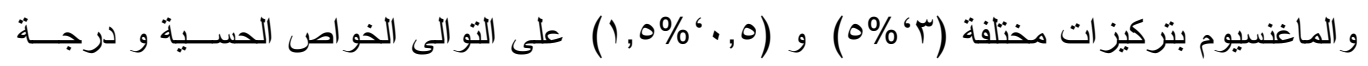

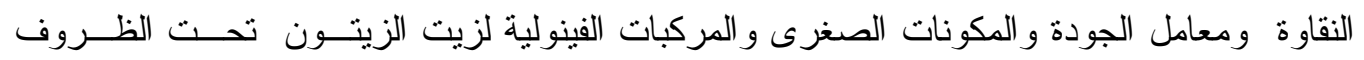

وقد أوضحت النتائج المتحصل عليها أن:

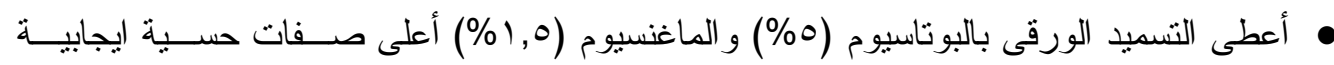

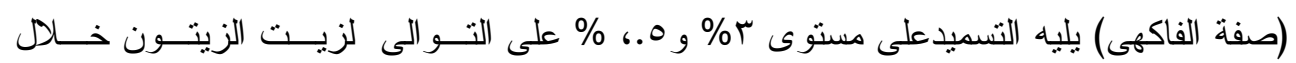

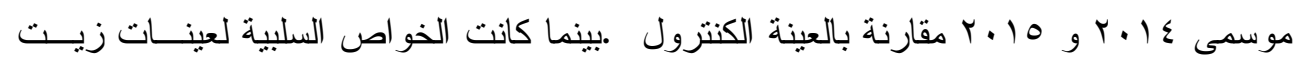

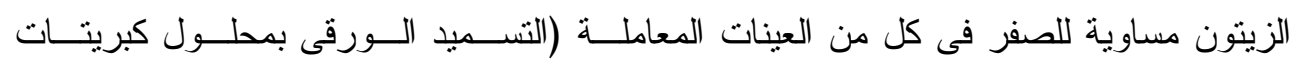

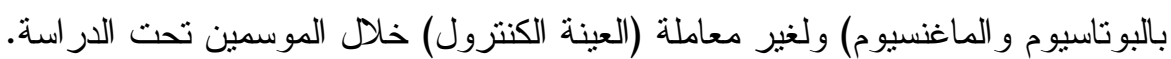

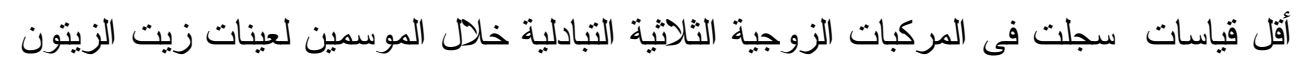
نتيجة للتسميد الورقى لاشجار الزيتون بمحلول كبريتات البوتاسيوم و الماغنيسيوم بمسنويات مختلفة مقارنة بعينات الكنترول فى حين سجلت SK زيادة بسيطة نتيجة لهذه المعاملات.

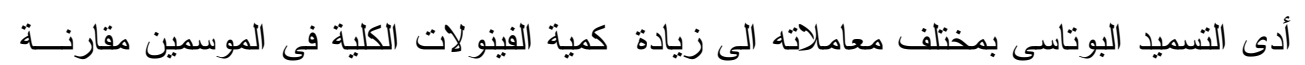

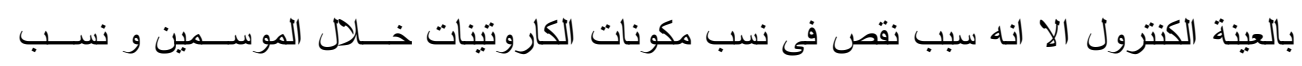

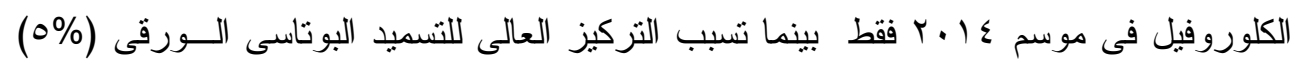
زيادة فى التوكوفيرو لات الكلية فى كلا الموسمين. •أدى التنميد الورقى بمحلول كبريتات البوتاسيوم و الماغنسيوم بمختلف التركيز ات الــى زيــادة مركب داى ارثوفينول فى زيت الزيتون مقارنة بالعينات الكنترول أثتاء الموسمين.

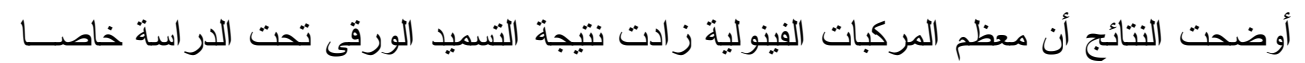
مركبات Oleuropein, Ellagic, Vanillic) خلال الموسمين مقارنة بالعينة الكنترول.

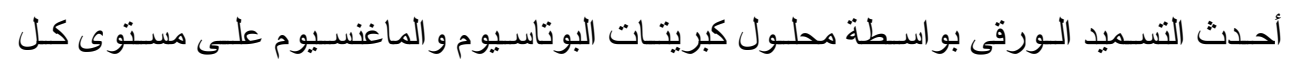

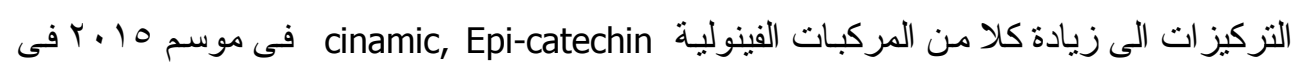
حين نقصت هذه المركبات فى موسم عـ الـ ب مقارنة بالعينة الكنترول. 